\title{
Foreword: Legislation and Lawgiving: Philosophical Perspectives on Antiquity
}

\author{
Dimitri El Murr \\ Professor of Ancient Philosophy, Department of Philosophy, \\ École Normale Supérieure - PS L University, Paris, France \\ dimitri.el.murr@ens.psl.eu

\begin{abstract}
Anthony Bonnemaison
Ph.D. Candidate in Ancient Philosophy, École Normale Supérieure PSL University, Paris, France

anthony.bonnemaison@gmail.com

René de Nicolay

Ph.D. Candidate in Ancient Philosophy, Princeton University, Princeton, NJ, USA; École Normale Supérieure - PSL University, Paris, France rnicolay@princeton.edu
\end{abstract}

In June 2019 - a not so distant past when scholars from all over the world could still come together and spend three days in the same room exchanging exciting views on difficult ancient texts - Melissa Lane (Princeton University) and I, Dimitri El Murr, assisted by two of our doctoral students, Anthony Bonnemaison and René de Nicolay, organized a conference at the École Normale Supérieure in Paris entitled 'Legislation and lawgiving: philosophical perspectives on Antiquity'. Our aim with this conference was to offer new philosophical perspectives on law giving (the issuing or writing of real or imagined constitutions for specific peoples) and more generally on legislation in classical antiquity; but we also sought to cover as much historical ground as possible, taking into account a wide range of philosophical traditions, from the Presocratics to Hellenistic philosophers and late Neoplatonists, with a special focus on the different conceptions these traditions develop of the legislator, from a critical as well as a positive point of view. The first drafts of the thirteen papers included in this volume were presented and discussed in Paris, and comments were sent to authors on the final drafts by Anthony Bonnemaison, René de Nicolay and myself. 
The order in which these articles are presented roughly corresponds to the chronology of their respective focus. The volume opens with Anders Dahl Sørensen's article which proposes a new reading of the fragments of Anonymous Iamblichi and argues that they offer two distinct approaches to nomos: a defense of nomos against the champions of natural pleonexia and a polemical approach directed against contemporary Athens.

Plato is the focus of the next seven papers and somewhat unsurprisingly, gets the lion's share of the volume. Phillip Horky's contribution focusses on the Republic, notably on a passage in book 2 in which Glaucon ascribes to Thrasymachus and 'countless others' a social contract theory. Using Anonymous Iamblichi, Xenophon, and testimonies from other Socratics on works On Justice or On Law now lost, Horky sheds new light on these 'countless others' and Glaucon's allusion which, he argues, is directed chiefly, but not solely, at the circle of Socrates. Also devoted to the Republic, Anthony Bonnemaison's paper examines why the curriculum of the philosopher-ruler, which notably aims at making lawful individuals, includes as one of its important steps the practice of refutation which Plato sees as possibly leading to lawlessness. Bonnemaison contends that for Plato, lawlessness is a risk that one should be ready to take to educate properly true dialecticians who should also be true rulers. The next contribution examines Plato's views on the art of legislation (nomothetikē) within the broader context of the Statesman, a dialogue which, more often than not, has been read as offering a vivid criticism of legislation. Although there is no doubt that exhibiting the flaws and limitations of the rule of law is an important part of Plato's agenda in the Statesman, I argue in this paper that legislation is nonetheless an indispensable tool for the ideal statesman to such an extent that Plato considers nomothetike an even more 'precious' art than rhetoric, strategy and the art of the judge directly subordinated to the statesman.

The next four papers deal with the most impressive and wide-ranging ancient philosophical work on legislation and lawgiving: Plato's Laws. Offering a broad comparative perspective on Plato's project in the Laws, Malcolm Schofield draws attention to the importance of Xenophon's Constitutions of the Lacedaemonians for understanding this project. On crucial features of the dialogue such as virtue as the goal of statecraft, the role of law in fostering proper conduct for the individual throughout his life, or the Spartan background of the entire legislative programme, Schofield argues that Plato expected his readers to detect the echoes of the programme attributed to Lycurgus by Xenophon. Myrthe L. Bartels' contribution examines in detail one of these features - the durability of law codes following individuals throughout all stages 
of their lives - through the lens of the concept of eunomia. She shows that within fourth-century constitutional debates, eunomia entailed not only the excellence of the laws but their permanence and durability as well, two aspects of the law she then considers in more detail in the fragments of Anonymous Iamblichi and Plato's Laws. The next two papers by René de Nicolay and Susan Sauvé Meyer also echo one another, as both examine the role ascribed to freedom (eleutheria) in Plato's constitutional analysis in the Laws. Focusing on the critical aspect of this analysis, René de Nicolay studies Plato's description of the transition from moderate to excessive and unlawful freedom and offers a new reading of the passage on theatrocracy in Book 3. Susan Sauvé Meyer's paper tackles the positive approach to freedom distinctive of the Laws, in which Plato claims that a good legislator should bestow freedom, wisdom, and friendship to the polis. Sauvé Meyer argues that such freedom is best understood as a freedom based on equality, mitigating the inequality between rulers and ruled.

Among the many readers of Plato's Laws throughout history, Aristotle stands out as one of the first but also one of the most acute. Starting from Aristotle's debt to Plato's Laws (and Statesman), Mitzi Lee's paper shows that much of Aristotle's own solutions and general optimism about the legislative capacity of political science come from Plato.

With Katja Maria Vogt's paper on the Stoic conception of law, we move from a narrow political understanding of nomos to a much wider conception of the law identified with the active and corporeal principle pervading the entire universe, and thus governing the cosmos as well as the actions of individuals within it. But how can the very same law be a corporeal principle governing the universe and a normative principle for us? Such is the puzzle raised by Vogt who departs from earlier interpretations of Stoic law which make it a set of rules. Against this dogmatic, universal understanding of Stoic law, and against the equally dogmatic, earlier political conceptions of laws and constitutions as aiming at fostering virtue or other values, the Pyrrhonian approach to laws and customs described by Sextus Empiricus acts as a powerful antidote. Discussing the so-called attitude of 'sceptical conformism', Stéphane Marchand claims that it should not be understood as indifference to politics, paving the way to mere acceptance and weak compromise, but as a criticism of fanaticism and praise for political caution.

Valentina Arena's paper takes us to Rome and to the late Republic in the second half of the first century вс. She reconstructs the intellectual debates that took place on the nature of the consulship in the works of the so-called antiquarians (especially Varro), and shows that these important constitutional 
debates were grounded on the etymological research borrowed from earlier philosophical approaches to the origins of language, notably Plato's in the Cratylus. More than four centuries later, but still in Rome, Julian the Emperor makes no mystery of his Platonic heritage. How is Julian's Platonism alive in his conceptions of law and legislation? How do they cohere with his distinct Neoplatonic understanding of the universe? Conversely, how does Julian's legislation and conception of the legislator reflect his own use of Plato's Republic, Statesman, and Laws? Such are the main questions raised by Dominic O'Meara's paper which not only surveys Julian's views about laws and legislation, but most importantly, considers the Roman Emperor a serious Platonic philosopher.

I wish to conclude this introduction by expressing my gratitude to all the contributors whose scholarly competence and diligence have made the preparation of this volume a very smooth and enjoyable experience; to Thornton Lockwood, Editor-in-Chief of Polis, for his benevolent assistance throughout the whole process; to my associate editors, Anthony Bonnemaison and René de Nicolay, with whom I had the pleasure to discuss the papers in this volume and who read each of them with great care and perceptiveness. Last but not least, my warmest thanks go to my dear friend Melissa Lane who designed the whole project with me, but sadly could not attend the Paris conference. 